\title{
EKOKRITIK SASTRA: SEBUAH KEARIFAN LINGKUNGAN DALAM NOVEL 'PING! A MESSAGE FROM BORNEO'
}

Oleh:

\author{
A. A. Kade Sri Yudari \\ Sriyudari15@gmail.com \\ Universitas Hindu Indonesia \\ Denpasar
}

Proses review 13-25 April, Dinyatakan Lolos 27 April

\begin{abstract}
Environmental crisis occurs because of human activity. Humans often lack understanding of nature and have difficulty creating a good relationship with the environment. This article discusses the relationship between humans and the environment contained in the novel 'Ping! A Messages from Borneo'by Riawani Eyta and Shabrina W.S. In this article analyzed are the elements of the narrative structure in the novel with an ecocritical approach. The results of the analysis and conclusions found from the novel contain a main idea that human nature and nature are one. A complete and strong message is conveyed by the author to Indonesian youth to care about logging forests and endangered species, especially the 'orangutan' in Kalimantan.
\end{abstract}

Keywords: Literary Criticism, Environmental Wisdom, Novel.

\begin{abstract}
Abstrak
Krisis lingkungan terjadi karena ulah manusia. Manusia sering kurang memahami alam dan memiliki kesulitan untuk menciptakan sebuah relasi yang baik dengan lingkungan hidupnya. Artikel ini membahas relasi antara manusia dan lingkungan hidup yang terdapat dalam novel 'Ping! A Message from Borneo' karya Riawani Elyta dan Shabrina W.S. Dalam artikel ini, yang dianalisis adalah unsur-unsur struktur naratif pada novel dengan pendekatan ekokritik. Hasil analisis dan kesimpulan yang ditemukan dari novel tersebut mengandung sebuah gagasan utama bahwa hakikat manusia dan alam adalah satu. Adanya pesan yang utuh dan kuat disampaikan oleh pengarang kepada para remaja Indonesia untuk peduli terhadap pembalakan hutan dan satwa langka, khususnya orang utan di Kalimantan.
\end{abstract}

Kata Kunci: Ekokritik Sastra, Kearifan Lingkungan, Novel. 


\section{PENDAHULUAN}

Bumi akan selalu mengalami perubahan. Setiap pertumbuhan dan perkembangan dalam kehidupan juga selalu membawa perubahan terhadap bumi. Kenaikan jumlah populasi manusia yang melebihi kapasitas normal dan kemajuan teknologi yang begitu cepat telah menyumbangkan berbagai dampak tak terduga terhadap bumi ini. Namun, aktivitas manusia di bumi dapat membuat status bumi dalam kondisi yang kritis.

Krisis lingkungan adalah masalah yang pelik. Planet bumi terus mengalami transformasi dari waktu ke waktu. Setiap hari proses itu terjadi semakin cepat. Al Gore, seorang aktivis Amerika yang gigih menyuarakan keprihatinan terhadap pemanasan global, menyebut situasi seperti itu dengan "new period of hyper-change". Sebutan tersebut bertitik tolak dari sebuah premis bahwa kita hidup di zaman yang berubah sangat cepat dan mendalam (Basuki, 2013:66). Kekacauan radikal dalam hubungan manusia dengan ekosistem semesta adalah alasan yang paling fundamental dari perubahan global. Hal tersebut muncul karena ada pandangan dunia yang berwatak Cartesian-Newtonian meletakkan manusia dalam posisi mendominasi alam dan inilah yang menimbulkan kekacauan radikal.

Di bidang sastra, situasi beberapa hutan yang sedang sekarat menginspirasi beberapa pengarang Indonesia untuk menulis karyakarya yang mengangkat isu lingkungan. Salah satu contohnya adalah novel 'Ping! A Messages from Borneo' (2012) karya Riawani Elyta dan Shabrina W.S. Novel setebal 142 halaman, penerbit Bentang Belia dengan cetakan pertama Maret 2012 oleh pengarangnya yang terpicu dengan keadaan hutan Kalimantan terutama satwa langkanya saat ini sungguh menyedihkan. Selain itu, pengarang terinspirasi dari sebuah buku yang membicarakan ekologi berjudul: 'The Coming Global Superstorm' (1999) karya Art Bell Strieber. Buku tersebut juga menginspirasi pembuatan film The Day After Tomorrow (2004). Dalam buku tersebut ada dugaan-dugaan atau kemungkinan kerusakan hutan diakibatkan bukan saja oleh alam bahkan karena ulah manusia, namun bukti-bukti tersebut dengan nyata diacuhkan (Junaidi, 2006).

Dengan tidak meninggalkan kesetiaannya pada tema-tema sebelumnya, pada episode kali ini pengarang nampak memberi porsi lebih besar untuk membicarakan masalah kesadaran berlingkungan hidup. Novel ini banyak pertanyaan seperti tentang asal-usul satwa langka dan kondisi orangutan yang mendiami hutan Borneo. Pertanyaan-pertanyaan tersebut dituturkan melalui narasi tokoh Molly yang memiliki kedekatan erat dengan alam. Menurut pengarang, pesan utamanya kurang lebih untuk menggeser perspektif manusia yang awalnya menganggap diri sebagai penguasa hutan menjadi pemelihara hutan.

Novel 'Ping! A Messages from Borneo' didaulat sebagai juara satu lomba Novel 30 Hari 30 Buku penerbit Bentang Belia. Merupakan novel remaja yang memberikan pandangan berbeda tentang kehidupan remaja dan isu lingkungan. Novel yang tidak begitu tebal ini ditulis oleh dua orang pengarang berikut konten di dalamnya pun terdiri dari dua sudut pandang yang mengangkat problematika miris perusakan lingkungan. Karya sastra ini, memadukan antara literature remaja dan fable dengan pengolahan yang sangat lincah padahal kedua pengarangnya belum pernah bertatap muka langsung hanya melalui media social.

Permasalahan yang ditonjolkan dalam novel ini adalah tentang hutan dengan segala isinya. Konsep lingkungan hidup dalam artikel ini mencakup segala sesuatu di alam semesta, seperti; hutan beserta isinya, sungai, orangutan, hewan liar, dan satwa langka lainnya. Isu lingkungan yang dideskripsikan dalam novel 'Ping! A Messages from Borneo' sangat dekat dengan situasi krisis lingkungan terhadap orangutan di hutan Borneo (Kalimantan). Oleh karena itu, hipotesis yang muncul adalah kritikkritik atas perilaku manusia terhadap lingkungan hutannya. Factor pemicu terbesar masalah lingkungan adalah ulah manusia, permasalahan lain yaitu bagaimana perilaku dan pemikiran manusia yang diwakili oleh tokoh-tokoh remaja dalam novel ini ketika memandang situasi lingkungan hutannya seperti itu. Dengan demikian, penulisan artikel ini bertujuan untuk memahami perilaku dan pemikiran manusia yang diwakili oleh tokoh- 
tokoh remaja dalam novel melalui pendekatan ekokritik yang dipandang relative baru sehingga dapat memberikan perspektif berbeda dalam karya ilmiah bidang sastra di Indonesia.

\section{Orientasi Teoretis dan Metodologi}

Penulisan artikel ini membutuhkan pemahaman yang jelas tentang hubungan dua arah antara unsur instrinsik dan unsur ekstrinsik. Dalam arti, penulis menggunakan analisis unsur instrinsik teks terlebih dahulu sebelum pembahasan dengan pendekatan ekokritik. Penulis melihat setidaknya ada empat elemen atau unsur terpenting dari struktur naratif yang menjadi pokok bahasan novel ini. Bahwa struktur naratif sebuah novel dibentuk oleh struktur dan isi. Struktur sering disebut bentuk (form), yang mengandung sejumlah isi (content). Untuk analisis isi, ukuran kriteria yang digunakan adalah unsur tema, plot/alur, latar dan tokoh atau penokohan. Sedangkan analisis bentuk, penulis gunakan unsur sudut pandang pengarang.

Berikutnya, pendekatan ekokritik atau ekokritism berfungsi meninjau ulang peranan manusia dalam menyikapi alam dan lingkungannya melalui karya sastra. Sebelum kemunculan pendekatan ini ranah kesusastraan selalu diragukan kontribusinya terhadap krisis lingkungan. Namun dengan pendekatan ekokritik ini, menunjukkan bahwa bidang sastra dapat berperan penting dalam menghadapi tantangan zaman yaitu krisis lingkungan hidup. Sebuah karya sastra dapat diinterpretasi menjadi sebuah artikel ilmiah sastra yang peka terhadap masalah lingkungan hidup. Dengan demikian, penulisan artikel ini juga bertujuan menggali kepekaan terhadap karya yang menampilkan problematika krisis lingkungan.

Dalam buku yang berjudul 'The closing Circle', Barry Commoner (1974:16), seorang ahli ekologi, menjelaskan bahwa dalil pertama dari ekologi adalah "everything is connected to everything else" (segala sesuatu terhubung dengan sesuatu yang lain). Dalil ini memberi peluang bagi pemikiran-pemikiran yang mengaitkan konsep ekologi dengan bidang sastra. Kehadiran karya sastra yang berorientasi lingkungan hidup, menurut dalil tersebut terhubung dengan pembacanya. Keterkaitan antara pembaca dengan karya sastra, melalui kajian ekokritism dapat memengaruhi hubungan manusia terhadap alamnyadi dalam kehidupan nyata.

Pendekatan ekokritik dalam novel ini bermanfaat untuk meningkatkan kesadaran manusia terhadap situasi alam khususnya hutan melalui karya sastra. Kesadaran berpikir secara ekologis ini penting untuk keberlangsungan hidup di bumu ini. Sebagai sebuah pendekatan sastra, ekokritism menyediakan kerangka kerja atau mekanisme untuk menganalisis teks-teks budaya dan sastra yang secara langsung maupun tidak langsung terkait dengan masalah ekologi sehingga dapat memperoleh gambaran atas relasi manusia dengan lingkungan hidupnya seperti yang terdapat dalam novel 'Ping! A Messages from Borneo'.

Berbeda dari pendekatan sastra yang lain, yang hanya mengkaji hubungan antara pengarang, teks, dan dunia social. Sedangkan ekokritism tidak melihat 'dunia' sebagai permasalahan social saja tetapi permasalahan alam semesta. Krisis lingkungan hutan meninggalkan banyak pertanyaan untuk diselesaikan manusia. Di bidang sastra, kajian ekokritism berpangkal dari pernyataanpernyataan tentang; representasi alam dalam karya sastra, peran latar tempat dalam sebuah alur di dalam novel, nilai yang tersimpam dalam novel yang sesuai dengan konsep-konsep ekologi, dan cara sastra dalam mengubah hubungan umat manusia dengan alamnya.

Seiring perjalanan waktu, ekokritism dikembangkan melalui berbagai bidang ilmu. Walaupun demikian, ekokritism tetap berpegang pada satu premis yaitu kebudayaan manusia dan alam saling memengaruhi. Premis ini bertolak dari premis yang diusulkan oleh Barry Commoner. Hokum pertama dari ekologi adalah segala sesuatu saling berhubungan (Commoner, 1979:18). Kaitan antara kajian sastra dan konsep ekologi yakni sastra tidak hanya mengambang di atas permukaan yang membicarakan masalah estetika, tetapi juga berperan dalam sebuah system global yang sangat kompleks bahwa energy dan ide itu saling memengaruhi.

Artikel ini termasuk ulasan yang bersifat 
kritik praktis. Kritik ini menerapkan teori-teori sastra yang dapat dinyatakan secara eksplisit atau implisit (Pradopo, 1994:22). Kritik praktis yang dimaksud Pradopo yaitu analisis sastra melalui teks sastra dan pengarangnya. Kritik praktis ini dapat digunakan dalam kajian ekokritism karena pada dasarnya pendekatan ini adalah kombinasi metodologi sastra dengan lensa ekologi. Penulisan artikel ini menggunakan kritik induktif yakni kritik sastra yang menguraikan bagian-bagian sastra berdasarkan fenomena-fenomena yang ada secara objektif. Melalui kritik ini, penulis melihat teks secara objektif dan mengaitkannya dengan konsepkonsep sesuai pendekatan yang digunakan. Kombinasi pendekatan disesuaikan dengan konsep karena artikel ini lebih menekankan aspek hubungan manusia dengan lingkungan hidupnya. Metode yang digunakan adalah deskriptif analitik yang diterapkan dengan cara mendeskripsikan fakta-fakta disusul dengan analisis (Ratna, 2010:53).

\section{Analisis Struktur dan Isi Novel 'Ping! A Messages from Borneo'}

\section{Analisis Struktur/Bentuk (form)}

Seperti telah disebutkan sebelumnya bahwa untuk menganalisis unsur struktur Novel 'Ping! A Messages from Borneo' penulis berpedoman pada sudut pandang pengarang. Sedangkan kita ketahui pengarangnya dua orang yakni; Riawani Elyta dan Shabrina W.S. Hebatnya, kedua pengarang ini dalam menyusun karyanya dengan melakukan komunikasi hanya lewat media social (e-mail). Walaupun keduanya memiliki sudut pandang dan gaya bahasa yang berbeda, namun tetap tidak ke luar dari pakem dan aturan penulisannya, sehingga tetap terlihat serasi dan harmonis. Berikut gambaran ide pengarang sampai terbitnya Novel tersebut menurut versi masing-masing.

\section{Versi Riawani Elyta:}

Menurutnya, ide awal novel ini sesungguhnya dari Shabrina W.S. yaitu tentang isu penyelamatan hewan langka dalam hal ini orangutan di Kalimantan yang mengalami pemusnahan massal berikut hutan habitatnya akibat pembukaan lahan sawit. Karena merupakan misi dan niat mulia, maka sangat perlu untuk didukung dengan memberikan kepercayaan bahwa kekuatan misi adalah salah satu obor motivasi yang paling potensial.

Selanjutnya diadakan pembagian tugas dengan mengumpulkan, membaca, mempelajari, interkoneksi antara referensi satu dengan lainnya sebanyak-banyaknya. Dari sana lah muncul ide bahwa novel yang sedang digarap berkisah tentang aktivitas seputar hewan langka. Berikutnya dibuatlah outline termasuk synopsis untuk masing-masing bab. Dan rupanya kedua pengarang novel ini sepakat menulis berdasarkan 'pakem' masing-masing. Shabrina dengan genre fabelnya, dan Riawani bagian fiksinya.

Awalnya kedua pengarang ini merasa ragu pada harmonisasi hasil gabungan kedua genre karyanya, apalagi isunya cukup krusial. Kesepakatan juga dibuat dalam proses penulisan masing-masing harus disiplin dengan berpatokan pada synopsis. Terdapat dua cerita yang berjalan selang-seling dalam novel ini. Naskah yang sudah dikoreksi masing-masing dilakukan dengan dua arah (tukaran) sampai selesai walaupun tetap ada perbaikan dan penyempurnaan karena kedua genre cerita saling berkaitan. Novel ini memiliki penggambaran karakter yang baik serta jalinan cerita yang sederhana. Semua karakter tokoh dalam novel memperlihatkan sindiran halus sekaligus mengena. Berikutnya, tersiar lah pengumuman lomba novel remaja karakter tokoh dewasa dari Bentang Belia. Dengan persiapan sesuai kriteria lomba maka karya ini pun didaftarkan. Sungguh tidak disangka dan sangat mengagetkan karena berhasil menjadi pemenang 1 (pertama) yang merupakan anugerah potensi dan kekuatan diri untuk mendedikasikan visi dan misi kebaikan serta kemanusiaan.

\section{Versi Shabrina W.S :}

Perjalanannya sebagian sudah diceritakan oleh temannya Riawani. Saat ada berita pembantaian orangutan betapa sedihnya dia membayangkan mereka sangat menderita. Sebelum berpikir melakukan sesuatu, yang dilakukannya adalah mengikuti petisi save orangutan, tiba-tiba berpikir untuk 
memperpanjang cerpen menjadi novel, ditawari lah novelis Riawani untuk duet. Setelah diadakan kesepakatan dimulailah dengan gaya penulisan masing-masing, mencari info dan referensi tentang orangutan serta habitatnya. Selanjutnya mencari info untuk setting

Berhari-hari khayalannya ada di Kalimantan karena sudut pandangnya orangutan membuatnya serasa menjadi orangutan, dan bagaimana penderitaannya. Demikian juga saat datang ke kebon binatang Surabaya mencari inspirasi dengan menemui orangutan, menatap dan melihat gerak-geriknya. Menurutnya inilah tulisan yang dalam penggarapannya paling serius dan semangat mencari referensi. Karena didasari atas kesadaran mencari misi isu penting bukan hanya untuk Indonesia tetapi dunia. Selain itu, orangutan merupakan ikon solusi pemanasan global. Ketika lapisan es di kutub mencair, beruang kutub menderita dan sengsara, demikian juga orangutan di tanah Borneo dengan sifat-sifatnya yang bisa memperbaiki hutan, adalah sebagai perbandingan untuk solusinya.

Selanjutnya, naskah disatukan, memang tidak mudah melebur genre yang berbeda tentu saling koreksi seperti bermain puzzle berdua. Setelah merasa utuh barulah dikirim, walaupun merasa tidak yakin tetapi tetap berdoa untuk optimis karena novel ini mengangkat isu penting yang sedang menghangat. Apalagi dipadukan melalui cara yang tak biasa antara fiksi remaja dengan fable. Namun keduanya tetap berusaha memenuhi syarat Bentang yaitu ringan. Sehingga akhirnya, yang diharap berhasil dengan luar biasa. Inilah pelajaran yang tidak dapat dinilai dengan rupiah.

\section{Analisis Isi (Content)}

Dalam novel tersebut penulis melihat ada empat unsur naratif yakni; latar, tema, plot/alur dan tokoh atau penokohan, masing-masing memiliki posisi penting untuk membentuk cerita. Secara umum, latar berkaitan dengan lokasi dan waktu berlangsungnya suatu peristiwa di dalam novel. Dalam novel 'Ping! A Messages from Borneo'memiliki latar yang kuat karena setiap peristiwa terjadi pada sebuah lokasi yang spesifik antar latar tempat dan latar social yang saling membaur.
Latar tempat berkaitan erat dengan keberadaan satwa langka khususnya perlindungan orangutan di hutan Kalimantan Timur. Memamg Kalimantan memiliki porsi pelataran yang lebih besar daripada latar lainnya. Analisis latar berguna untuk mengidentifikasi masalah-masalah yang berkaitan dengan relasi antara para tokoh dan alamnya. Telaah latar tempat di Kalimantan mengidentifikasi bahwa pada latar tersebut terjadi masalah.

Latar tempat menggambarkan ide pemikiran para pengusaha melalui penduduk setempat yang berambisi memusnahkan hutan untuk dijadikan lahan perkebunan kelapa sawit, sehingga harus membantai isi hutan beserta habitatnya dengan cara yang sangat miris. Pemikiran itu merupakan sebuah contoh sifat manusia yang lebih sering memikirkan keuntungan ekonomi diri sendiri daripada memikirkan keseimbangan ekosistem. Deskripsi peristiwa-peristiwa menggambarkan perwakilan atas kondisi Kalimantan secara garis besar.

Melalui berbagai kejadian yang berlangsung ada dua topic masalah lingkungan yang hendak diutamakan yaitu; kepunahan spesies fauna dalam hal ini orangutan dan kerusakan ekosistem lingkungan hidup akibat aktivitas perkebunan kelapa sawit dengan pembabatan/ pembakaran hutan secara illegal yang tidak bertanggung jawab. Setting tempat mengambil kawasan Kutai Kartanegara (Kukar) juga sedikit tentang Samboja Lestari yang dieksplor dengan baik dan mengalir jelas. Novel ini, plot/alur ceritanya tidak begitu rumit mungkin karena kedua penulisnya sepakat ingin lebih menekankan aspek penyampaian amanah yang menampar bagi pembaca. Tidak terlalu banyak teka-teki sehingga mudah diterka endingnya.

Tema novel dengan aliran ini mungkin jarang ditemui karena kebanyakan novel remaja menekankan tema pada lini romance dan minim amanah tajam. Dengan kehadiran novel ini seharusnya mampu melahirkan buah ide di kalangan novel remaja mainsteam dan sudah saatnya literature remaja di Indonesia mengangkat hal-hal krusial yang kemungkinan jarang disinggung tidak melulu hal-hal yang sifatnya klise. 
Kisahnya diawali dengan halaman pembuka berjudul 'Sketsa Luka', bab yang begitu miris karena dari sinilah kita akan tahu penderitaan yang dialami seekor anak orangutan (Ping atau Karro) yang kehilangan induknya padahal dia masih kecil. Juga problematika yang ada dihadapannya, seperti kerusakan hutan dengan habitatnya, membuat dia terus-menerus berpikiran negative, bahkan trauma dan merasa kesepian. Pada bab selanjutnya, kita dapat membaca kisah Molly yang ditelepon teman masa kecilnya bernama Nick, seorang bule genius yang kuliah di Program Wildlife Conservation University of Chester yang berencana mengajak Molly melakukan konservasi di Pulau Borneo, menyelidiki kasus yang akhir-akhir ini marak diperbincangkan yaitu kerusakan lingkungan dan misi penyelamatan orangutan di Kalimantan.

Analisis tokoh dan penokohan dilakukan untuk mengetahui pemikiran dan tindakan para tokoh cerita terhadap alamnya. Cerita dalam novel 'Ping! A Messages from Borneo' melibatkan empat tokoh utama (manusia) dan seorang tokoh penyerta sebagai objek (orangutan). Pada bab-bab selanjutnya, dituturkan petualangan Molly, Nick dan kawan Nick bernama Andrey di Kalimantan, merupakan sebuah perjalanan yang menyenangkan bagi Molly yang suka melakukan aksi penyelamatan satwa langka. Letupan konflik terjadi saatmereka bertiga dipertemukan dengan Archie, sahabat SMA Molly yang sudah setahun berpisah, seorang putra pengusaha kelapa sawit sekaligus penerus bisnis orang tuanya. Dan tidak lupa kisah tentang Karro (Ping) anak orangutan yang melanjutkan perjuangannya melawan para pemburu, diceritakan dengan sangat miris sampai akhirnya bertemu Molly sang penyelamat.

Molly adalah tokoh sentral yang sebenarnya mencuri perhatian pembaca karena aksinya menyelamatkan Karro (Ping), sifatnya sangat manusiawi saking cintanya terhadap lingkungan. Namun, ada hal yang mengganjal sikapnya saat Molly bersinggungan dengan Archie yang ternyata sudah berubah tidak mendukung (apatis) terhadap lingkungan secara tidak langsung membenci Molly karena aksinya. Namun, tidak dijelaskan apakah Archie ada rasa suka pada Molly atau tidak, seharusnya karakter
Molly bisa dipertajam ketika yang bersangkutan tahumasalah dihadapannyasangatberhubungan dengan kepentingan Archie. Di sela petualangannya, Molly yang bertemu Archie sahabatnya, putra tunggal seorang pengusaha Sawit yang menentang keras kegemaran Molly pada keselamatan Satwa. Dan bersikap tidak ramah terhadap Nick sehingga terjadi sedikit pertengkaran.

Sedangkan Karro atau Ping sudah bagus dengan sikap tanpa menyerah dan kebimbangannya adalah sikap yang wajar karena masih kanak-kanak. Berbeda Nick dan Andrey porsi mereka memang tidak terlalu banyak, namun pengarang dapat memperuncing konflik antara Archie dan Nick terkait kedua kepentingan tokoh tersebut yang bertolak belakang.

\section{PENUTUP}

Krisis lingkungan terjadi karena relasi antara manusia dengan lingkungannya tidak selaras. Hal ini disebabkan karena dua masalah yaitu manusia itu sendiri dan sifatnya yang tidak pernah puas. Untuk memahami relasi manusia dan lingkungan yang ada pada novel 'Ping! A Messages from Borneo' dilakukan melalui analisis unsur struktur dan isi teks naratif yang meliputi; tema, alur/plot, latar, tokoh/ penokohan dan sudut pandang pengarang.

Secara garis besar, novel 'Ping! A Messages from Borneo'menampilkan semangat seorang gadis remaja penyayang binatang bernama Molly yang nekat mengikuti ajakan Nick untuk meneliti keberadaan orangutan dan kepunahan spesiesnya di hutan Kalimantan Timur. Bahwa hutan di Kalimantan telah mengalami kerusakan ekosistem akibat ulah manusia yang serakah telah membabat dan membakarnya.

Teknik penulisan novel yang tidak mudah karena terdiri dari dua genre melebur jadi satu saling menutupi kekurangan dan mengisi peran dengan sebaik mungkin. Hebatnya, interaksi kedua pengarangnya hanya sebatas di dunia maya.

Dari analisis di atas, ada beberapa pesan untuk direnungkan oleh masyarakat luas, ingin disampaikan pengarang tentang pembabatan hutan yang membabi buta di Kalimantan antara 
lain; isu bisnis kelapa sawit yang tidak 'ramah' hutan, keprihatinan terhadap Ping alias Karro atas kematian induknya karena tempat tinggalnya dibakar paksa. Demikian juga Ping yang dipaksa keluar dari hutan karena mau dijual, dengan membakar hutannya terlebih dahulu.

Juga ada pesan lain dari novel ini, bahwa menulis bukanlah sesuatu yang menghambat kewajiban dan aktivitas lainnya. Menulis harusnya memiliki porsi yang pas dengan alokasi waktu yang membuat kita disiplin.

Kita dapat memetik pelajaran berharga dari novel ini mengenai kepedulian terhadap lingkungan dan habitat makhluk hidup yang seharusnya dijaga, bukan untuk dimusnahkan apalagi buat kepentingan pribadi. Di dalamnya terselip arti perpisahan dan kesakitan melebur jadi satu. Ping! merasakan semua yang dirasakan oleh manusia demikian sebaliknya pada Molly.

Walaupun novel remaja, unsur romantisme di dalam novel ini hampir tidak ada, hanya seperti angin yang melintas ketika Archie mengakui pernah ada perasaan sayang kepada Molly sejak mereka duduk di bangku SMA, namun seketika dialihkan pembicaraannya oleh Molly yang menandakan keteguhan hatinya karena merasa membawa misi untuk kepentingan dunia.

Dengan demikian, kajian ekokritik ini penting untuk diteruskan melalui bidang ilmu lain untuk membantu pembaca dalam memahami keadaan alam. Tentu dengan harapan dapat menyadarkan masyarakat pembaca dalam melestarikan alam dan segala isinya. Karena, relasi antara manusia dan alam lingkungannya harus tetap terjaga lestari dan harmonis. Apalagi orangutan sudah diakui dunia sebagai ikon pemanasan global.

\section{DAFTAR PUSTAKA}

Basuki, Dian. 2013. "Al Gore, Perubahan dan Demokrasi yang Ditawan”. Jakarta: Tempo, edisi 8, 14 April.

Commoner, Barry. 1974. The Closing Circle. New York: Bantam Books.

Forest Watch Indonesia (FWI).2001. Keadaan Hutan Indonesia. Bogor: Forest Watch Indonesia.

Junaidi, A.2 April 2006. "Dewi Dee Lestari Love, Spirituality, and Ecology”. The Jakarta Post. Diakses 17 April 2020, pukul 11.06 WITA.

Pradopo, Rachmat Djoko. 1994. Prinsip-prinsip Kritik Sastra. Yogyakarta: Gadjah Mada University Press.

Rampan, Korrie Layun.2000. "Wawasan Estetik Angkatan 2000 Dalam Sastra Indonesia”. Jakarta: Grasindo.

Riawani Elyta \& Shabrina, W.S. 2012. Novel: "Ping! A Messages from Borneo”. Jakarta: Bentang Belia Ratna, Nyoman Kutha. 2010. Teori, Metode, dan Teknik Penelitian Sastra dari Strukturalisme hingga Postrukturalisme Perspektif Wacana Naratif. Yogyakarta: Pustaka Pelajar. 